\title{
高張力鋼の高温変形下における結晶粒の 成長と挙動についで
}

\author{
田村 博** 加藤 昇** 渡辺健彦***

\section{On the behaviour and growth of grains of high strength steel during high temperature deformation*}

\author{
by Hiroshi Tamura**, Noboru Kato** and Takehiko Watanabe***
}

\begin{abstract}
The behaviour of grains and its boundaries in HAZ, accompanied with grain-coarsening and under stress conditions which are caused by solidification of weld metal or by welding heat, is related to hot cracking and embrittlement of HAZ. Moreover, grain-boundary migration plays an important role in hot working, creep and high temperature fatigue.

In this paper, the behaviour of austenite grains and its boundaries of high strength steel during tensile deformation at high temperature around $1300^{\circ} \mathrm{C}$ was studied with microscope.

The main conclusions obtained in this study are as follows:

(1) Wide fluctuation of load was observed in load-elongation curves during hot tensile deformation. It was verified that its phenomenon is caused by dynamic recrystallization. The higher rate of deformation at high temperature around $1300^{\circ} \mathrm{C}$ and the lower rate at somewhat lower temperature less than $1100^{\circ} \mathrm{C}$, the more easily dynamic recrystallization tends to occur.

(2) The higher rate of deformation at $1300^{\circ} \mathrm{C}$, the higher grain-boundary migration rate and the faster it was saturated.

(3) Migration of grain-boundary țriple point is caused by mechnical sliding at boundary and atomic diffusion. Consequently the triple point migrates alternately and zigzag.

(4) Dynamic recrystallized grains were observed. Its nuclei occured preferentially and accidentally at the place near boundary within a grain.
\end{abstract}

\section{1. 緒霄}

金属を溶接する際には，アーク熱などにより溶接金属 近傍の母材は広い範囲にわたってその融点から室温にい たるまでの複雑な熱サイクルを受け，結晶粒の粗大化や 微細化がおこる. また溶接金属の凝固時の収縮応力や溶. 接熱飞よる膨張，収縮と拘束が重畳し，乙の溶接金属近. 傍の結晶粒および結晶粒界には複雑な応力が作用する。 これらの現象がいわゆる溶接熱影響部の諸性質に著しい 影響を与える.特に，この際におてる結晶粒界の挙動は. 溶接熱影響部に生ずる高温割れとも密接に関連している と思われる。さらにまた，粒界の移動現象は熱間加工， クリープそして高温疲労などにす重要な役割りを演じて いる.

\footnotetext{
*原稿受付 䧂和46年 4 月21日（45年度秋李全国大会にて発表）

** 正. 員東京工業大学 Member, Tokyo Institute of Technology

***学绊員身宗工策大学 Student Member, Tokyo Institute of Technology
}

そこで本報告は $80 \mathrm{~kg} / \mathrm{mm}^{2}$ 級高張力堸を用い， 1300 ${ }^{\circ} \mathrm{C} \sim 900^{\circ} \mathrm{C}$ の間の温度で引張変形速度を種々变化させ, その間の絬晶粒界の挙動に引張型の高温顕微鏡を使用し て検討加えたすのである：

\section{2. 供試材および実験方法}

\section{$2 \cdot 1$ 供 試 材}

供試材には $80 \mathrm{~kg} / \mathrm{mm}^{2}$ 級調質高張力鈵（新日本製鉄 WT 80 板厚 $25 \mathrm{~mm}$ ) を用いた。 その化学成分ならびに 譏械的性犋を Table 1 亿示す.

\section{$2 \cdot 2$ 実·験'方法}

本実験に用いた高温顕微鏡は引張型でその外悔を Photo. 1 に示す. Fig. 1.は試験片形状で板厚は 1.5 $\mathrm{mm}$, 試験片中央部には約 $0.1 \mathrm{R}$ の切久きを設けてある が, これは高温顕微鏡で観察する場合に，塑性変形部が 常に検鏡視野に入るようにするためである。

奏験はまず試験片の中央部表面をバフ研磨したのちに 炉内に装填し, その後, 炣内を約 $2 \times 10^{-4} \mathrm{mmHg} の$ 真 
1040 論 文 田村, 加藤, 渡辺 : 高張力鋼の高温変形下における結晶粒の成長と挙動について

Table 1 Chemical compositions and mechanical properties of test steel.

\begin{tabular}{c|c|c|c|c|c|c|c|c|c|c}
\hline \multicolumn{9}{c}{ Chemical compositions (\%) } & \multicolumn{2}{c}{ Mechanical properties } \\
\hline $\mathrm{C}$ & $\mathrm{Si}$ & $\mathrm{Mn}$ & $\mathrm{P}$ & $\mathrm{S}$ & $\mathrm{Cu}$ & $\mathrm{Ni}$ & $\mathrm{Cr}$ & $\mathrm{Mo}$ & $\begin{array}{c}\text { Y.S } \\
\mathrm{kg} / \mathrm{mm} 2\end{array}$ \\
\hline 0.12 & 0.37 & 0.89 & 0.012 & 0.007 & 0.33 & 0.97 & 0.71 & 0.53 & $\begin{array}{c}\mathrm{T} . \mathrm{S} \\
\mathrm{kg} / \mathrm{mm} 2\end{array}$ \\
\hline
\end{tabular}

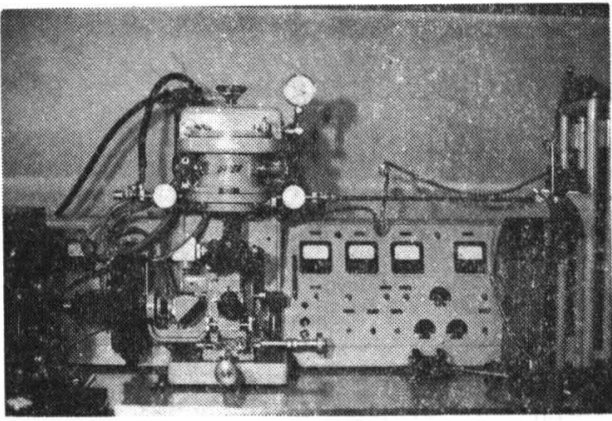

Photo. 1 View of apparatus used

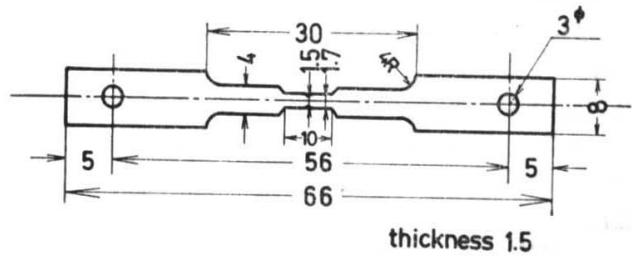

Fig. 1 Tensile test specimen. Rolling direction is perpendicular to this paper.

空にひき，つづいて高純度アルゴンガスを導入し，昵内 を1気圧アルゴン雾囲気とした．試験片の加熱は交流直 接通電により行ない, 加熱速度は $100^{\circ} \mathrm{C} / \mathrm{min}$ とした.

最初に, 試験片を $1350^{\circ} \mathrm{C}$ まで加熱し $\left(1350^{\circ} \mathrm{C}\right.$ の場 合に電圧約 $2 \mathrm{~V}$, 電流は約 $90 \mathrm{~A}$ であった.), ここで約 $1 \mathrm{~min}$ 間恒温保持し, 結晶粒を ASTM オーステナイト 粒度番号 No. 1 (約 300 400 $\mu$ ) 程度の大きさにした. ひきつづいて所定の温度（本実験の場合は $1300^{\circ} \mathrm{C}, 1200$ ${ }^{\circ} \mathrm{C}, 1100^{\circ} \mathrm{C}, 1000^{\circ} \mathrm{C}, 900^{\circ} \mathrm{C}$ ) まで下げ, その温度に保持 したままで引張変形を行ない，その間の結晶粒および粒 界の挙動を直接観察すると同時に写真撮影を行なった.

試作した引張装置は $1.85 \times 10^{-1}(\mathrm{~mm} / \mathrm{sec})-7.63 \times$ $10^{-4}(\mathrm{~mm} / \mathrm{sec})$ の 6 段階の引張速度を有しており, 高温 顕微鏡の炉体の引張軸之は $10 \mathrm{~mm} \phi$ の軟 鋼棒を介して 連結し, 試験片に引張丕を加えている.なおての連結棒 の一部にストレインゲージを貼りつけて引張変形途上の 荷重変動の様子をペンレコーダーで自動記録した．Fig.

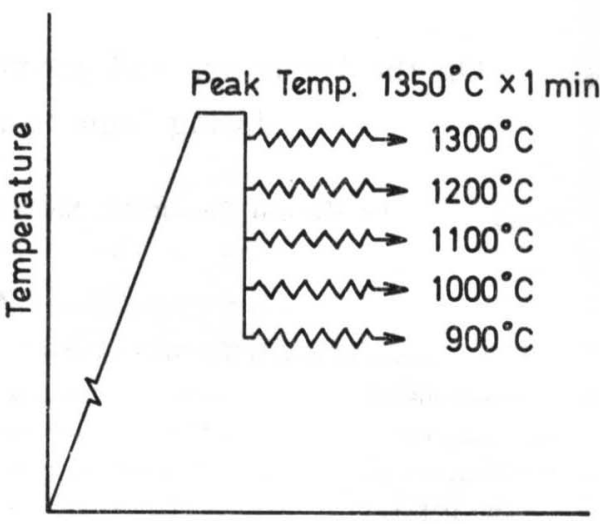

Time

Fig. 2 The thermal cycles used

2 亿実験に用いた熱サイクル図を, Table 2 に 6 段階の 引張速度を示し, 便宜上大きな引張速度から小さな引張 速度へと V1〜V6 の記号を付した。

\section{3.実験結果ならびに考察}

\section{3 - 1 䨌团気および試料表面仕上の影響についての} 予備的考察

通常高温顕微鏡による金属組織の観察は，あらかじめ 機械的に鏡面仕上げをした試料表面を真空中またはアル ゴンガスなどの不活性ガス雾囲気中で加熱し，熱腐食に より組織を現出させて行なう。このような場合, 高温度 亿加熱された試料表面は雾围気の作用に敏感であり, 原 子の拡散の模様なども表面と内部では異なることが当然 考えられる. また試験片製作過程，特に検鏡面仕上時の エメリーペーパー, バフ研摩による表面加工歪の組織に 対する影響などす考慮されねばならない。

したがって武料の表面観察に基づいてただちに内部の 状態を推論することは慎重を要するであろう．とれらの 点が高温顕微鏡を使用するに際して常につきまとう問題 ではあるが, しかしこれにあかかわらず従来, 高温顕微 鏡によって加熱冷却時の相変態, 高温における結晶粒成 長, 変形, 破断などが観察されており, かなりの成果を

Table 2 Tensile rates used.

\begin{tabular}{c|c|c|c|c|c|c|}
\hline \hline Symobol & V 1 & V 2 & V 3 & V 4 & V 5 \\
Rate $(\mathrm{mm} / \mathrm{s})$ & $1.85 \times 10^{-1}$ & $6.17 \times 10^{-2}$ & $2.06 \times 10^{-2}$ & $6.86 \times 10^{-3}$ & $2.29 \times 10^{-3}$ & $7.63 \times 10^{-4}$ \\
\hline
\end{tabular}


あげている。

そこで本研究を行なうにあたり，まず表面と内部の組 織を念のために本実験条件であらかじめ調べてみた。 れによると 1 気圧アルゴン雾囲気中での加熱では, 母材 から切り出し鏡面に仕上げたままの試験片と，それに表 面の切削や仕上げによる変形層の歪とりのため, $550^{\circ} \mathrm{C}$ で 1 時間の真空焼鈍を行なった試験片の両者之も表面組 織之内部組織はほぼ一致し，本実験の場合，1気压了ル ゴン加熱雾囲気および加工歪の影響はほとんどないもの と考えた。

なお凨本と宮川らりは， $\mathrm{Al}$ キルド $0.2 \% \mathrm{C}$ 鋼につい て加熱雾囲気および表面研磨法の表面組織に及ぼす影響 を研究している. それによると加熱雺囲気が $0.6 \sim 1$ 気 圧ア、ルゴンの場合は雲围気の影響はほ上んどなく，また エメリーペーパー, バフ研磨も同様にほとんど影響しな いとしている.

\section{3 - 2 高温引張変形下における荷重一伸び曲線}

本供試高張力鋼を先の Fig. 2 に示した加熱サイクル
に良ってそれぞれ $1300^{\circ} \mathrm{C}, 1200^{\circ} \mathrm{C}, 1100^{\circ} \mathrm{C}, 1000^{\circ} \mathrm{C}$, $900^{\circ} \mathrm{C}$ の各温度に恒温保持し, $\mathrm{V} 1 \sim \mathrm{V} 6$ の 6 段階の引張 速度で破断まで引張変形を加えた，その間の全伸び量と 変形途上の荷重変動の様子を Fig. 3 の ( a ), ( b ), ( c ), （d）（e）に示した．これらの荷重一伸び曲線に共通し ていえるこ之は, 引張変形途上で荷重が激しく変動して いるととである．乙の荷重の変動が引張装置の機構など 加らく詥差ではないことを確かめるために，アルミニ ウムを室温で引張りその荷重一伸び曲線を求めた．その 一例を Fig. 4 亿示した。これに見られるようにほぼ正 常な曲線が描かれており Fig. 3 の荷重変動は機械的な 誤差ではない之断定した。

高温変形には加工硬化と高活性化エネルギーを必要と する拡散, 相変化, 特に回復, 再結晶などが交互におて ると考えられる。ここにいう回復，再結晶はいずれる動 的なもので動的再結晶 (dynamic recrystallization) と 呼ばれ, 冷間加工材の焼なまし時におこる再結晶, いわ ゆる普通の再結晶 (static recrystallization) と区別さ
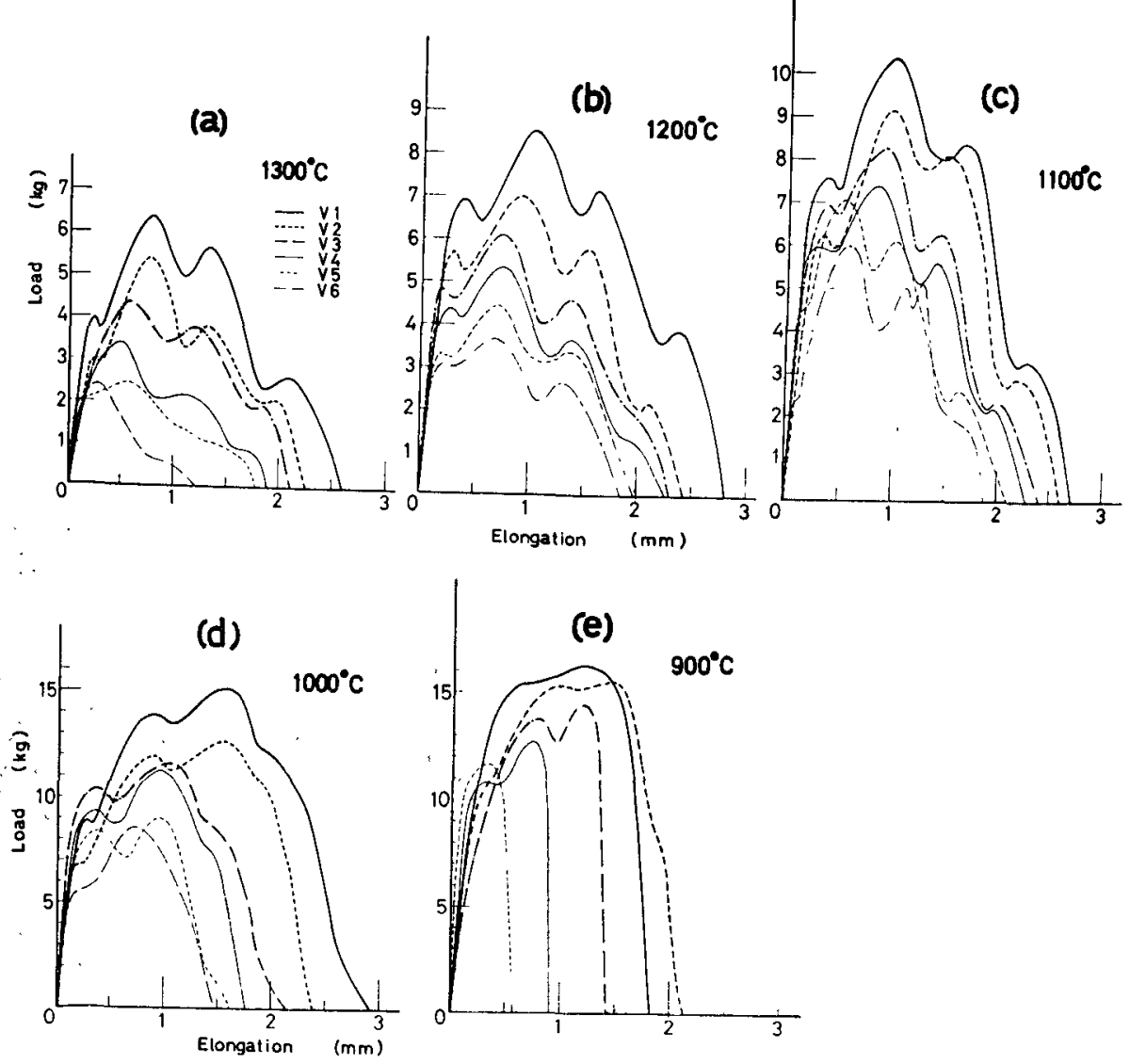

Fig. 3 Load-elongation curves of test specimens during tensile testing at various higher temperatures, according to the thermal cycles shown in Fig. 2 


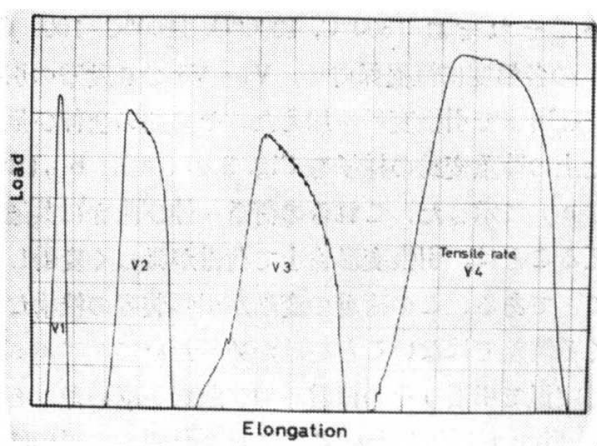

Fig. 4 Load-elongation curves of aluminium specimens

れている.

Fig. 3 の荷重一伸び曲線にみら机る荷重の変動は, こ の動的再結晶が於こるととによって現われるものと考え られる。

(1) $1300^{\circ} \mathrm{C}$ での変形における動的再結晶現象

Fig. 3 の（a）に示した $1300^{\circ} \mathrm{C}$ の場合をみると， $\mathrm{V} 1 \rightarrow \mathrm{V} 6$ へと引張速度が小さくなるにつれて荷重の変動 量が少なくなる傾向がみられるので, この $1300^{\circ} \mathrm{C}$ での 変形の場合をとりあげて, 荷重変動量の大きい場合とし て V2 $\left(6.17 \times 10^{-2} \mathrm{~mm} / \mathrm{sec}\right)$ の変形速度を考え, また 荷重の変動がほとんどみられない場合として V6 (7.63 $\left.\times 10^{-4} \mathrm{~mm} / \mathrm{sec}\right)$ の変形速度を考えて, 荷重一伸び曲線 にみられる荷重変動が動的再結晶に起因しているか否か を確かめた。

この動的再結晶を確加る方法としては, 第一に変形 後急冷を行ない試料の切断内部組織に再結晶粒が現われ ているか否かを調べるととにした. 本実験の場合, 急冷 とはいっても炉内の冷却速度は $1350^{\circ} \mathrm{C} \rightarrow 600^{\circ} \mathrm{C}$ までが (約 $75^{\circ} \mathrm{C} / \mathrm{sec}$ ) なので, 冷却中にいく分再結晶が進行す るであろうという見地から, 試料を除荷し急冷する時期 を引張変形途上でピーク荷重に対応する伸びより少し変 形が進んだところに選定した。
Photo. 2 がその急冷内部組織であり，（a ）は試料に 歪を加える前の $1350^{\circ} \mathrm{C}$ に 1 分間恒温保持をした後の内 部組織であり大きなオーステナイト結晶粒がみられる. （b）は V 2 の高速度で引張った場合の内部組織で, 微 細なオーステナイト結晶粒が観察され明らかに再結晶が おこったととを示すあのである.（c）は同じくＶ６，の 低速度で引張ったもので, 大きなオーステナイト結晶粒 のみで微細化は見られず再結晶はおてっていないととが わかる.との大きなオーステナイト粒内にはいわゆる脈 状組織が観察されている。な挍食液としてはピクリン 酸飽和水溶液 $100 \mathrm{cc}$ に対し, 界面活性剂としてウラリ ルベンゼンスルフォン酸ソーダ $0.2 \mathrm{~g}$ を加えたものを使 用した.

次に動的再結晶を確認する第二の方法として高温顕微 鏡を用いて再結晶粒を直接観察した，そのためにやは り, $1300^{\circ} \mathrm{C}$ で V2 の速度で引張り Photo. 2 の (b ) と 同一場所で除荷し, その温度に恒温保持しその間の組 織変化を直接観察し写真撮影を行なった。 その模様を Photo. 3 (a) に示す.（1）は引張変形前の組織で, た またま中央に異常成長した大きなオーステナイト粒 Aが みられる.（2）は変形途上で除荷した直後の組織であ り,A粒がかなりの変形を受けている.（3）は恒温保 持 1 分後の組織で $\mathrm{A}$ 粒内に新しい結晶粒がみられ, てれ が再結晶粒之思われる. (4) は恒温保持 30 分後のあの で, 再結晶粒界の幅が広がっていることから, この再結 晶粒界が移動し成長しているととがうかがえる.（5） は保持40分後の組織で粒界移動の痕跡がはっきりとみら れる. (矢印)

Photo. 3 (b) は $1300^{\circ} \mathrm{C}$ で荷重変動がほとんどなか ったV6 の低速度で引張りを与えた場合で, やはり変形 途上で除荷し恒温保持の間の組織変化を示したものであ る.（1）は荷重を作用させる前の組織である.（2）, （3）は引張変形途上のもので, 結晶粒界の激しい移動 がみられる. (4) は Photo. 2 の (c) と同一の変形量

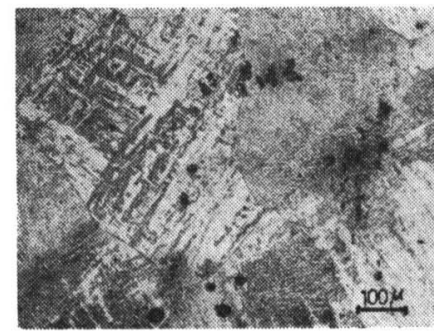

(a)

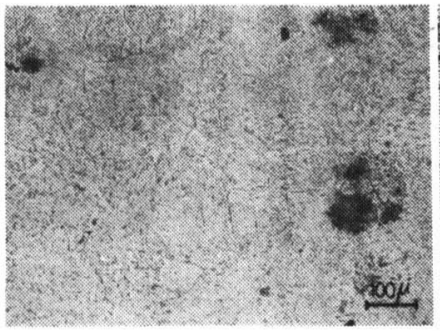

( b )

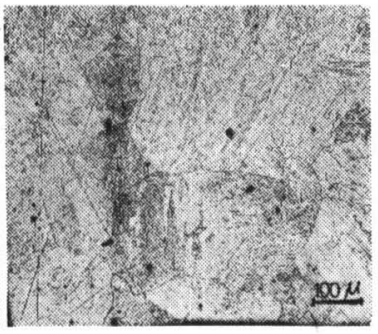

(c)

Photo. 2 Microstructures of quenched specimens before and after deformation
(a) Before deformation
(c) Deformed at $1300^{\circ} \mathrm{C}, \mathrm{V} 6$
(b) Deformed at $1300^{\circ} \mathrm{C}, \mathrm{V} 2$ 


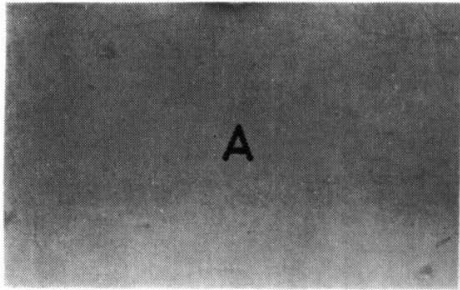

(1)

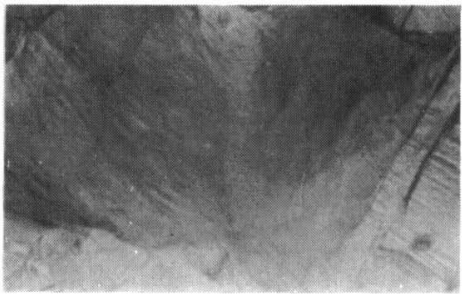

(2)

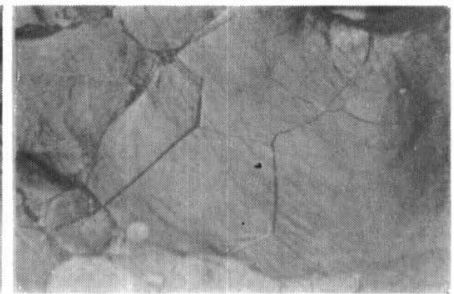

(3)

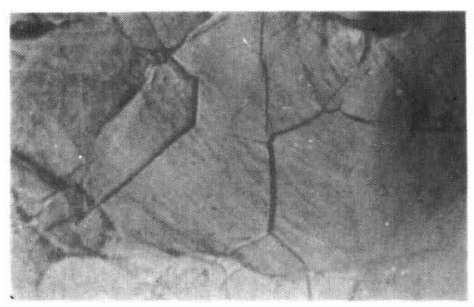

(4)

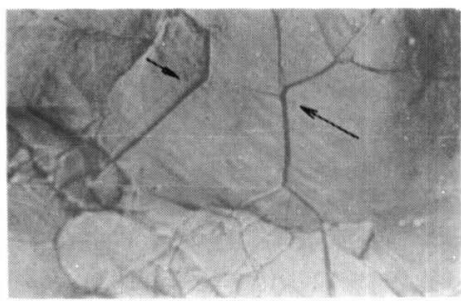

( 5 )

Photo. 3 (a) Isothermally holded high temperature structures after deformation at $1300^{\circ} \mathrm{C}, \mathrm{V} 2(\times 70 \times 7 / 10)$
(1) Before deformation
(4) After holding for $30 \mathrm{~min}$
(2) Immediately after unloading
(5) After holding for $40 \mathrm{~min}$

(3) After holding for $1 \mathrm{~min}$

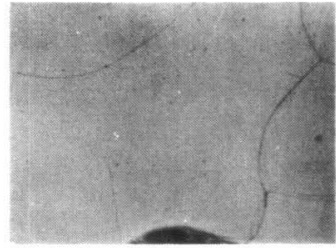

(1)

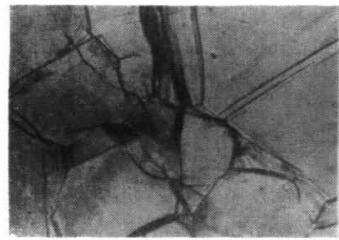

(5)

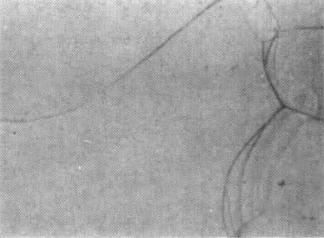

(2)

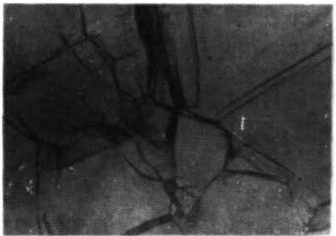

(6)

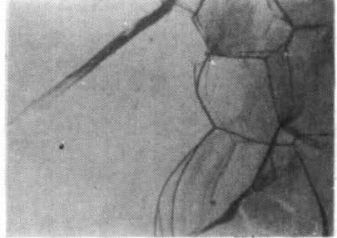

(3)

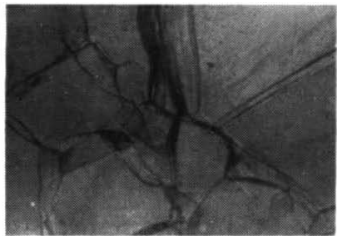

( 7 )

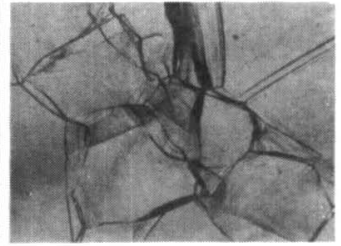

(4)

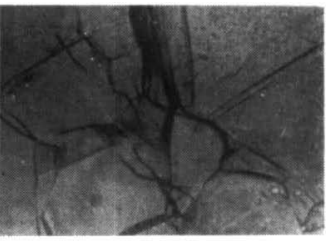

(8)

Photo. 3-(b) Isothermally holded high temperature structures after deformation at $1300^{\circ} \mathrm{C}$, V2 $(\times 70 \times 7 / 12)$
(1) Before deformation
(2),(3) During deformation
(5) After holding for $2 \mathrm{~min}$
(4) Immediately after unloading
(6) After holding for $5 \mathrm{~min}$
(7) After holding for $7 \mathrm{~min}$
(8) After holding for $20 \mathrm{~min}$

のところで除荷した直後の組織であり，（2)，（3）の 撮影個所とは異なるところであるが, 粒界が激しく移動 したあとがわかる。（5）は恒温保持 2 分後の組織であ るが,なんらの変化もみられない，(6)，（7)，（8） はそれぞれ 5 分後, 7 分後, 20 分後であるがなんら組織 変化はみられず, 再結晶粒の出現はなかった.
以上の急冷切断による組織観察結果および高温顕微鏡 による直接観察結果から Fig. 3 の荷重一伸び曲線にみ られる荷重変動の波は動的再結晶によって現われ, 加工 硬化と軟化が交互におこっているためであると解釈し た.

（2）動的再結晶におよぼす引張丕速度の影響 
次に $1100^{\circ} \mathrm{C}$ で引張りを加えた時の荷重一伸び曲線 [Fig. 3(c)] では荷重変動すなわち動的再結晶の傾向は $1300^{\circ} \mathrm{C}$ の場合上逆になっている。 つまり $\mathrm{V} 1 \rightarrow \mathrm{V} 6$ へと 引張速度が小さくなるにつれて荷重変動量が大きくなっ ている。ささらに $1000^{\circ} \mathrm{C}, 900^{\circ} \mathrm{C}$ と温度が下がるにつれ て，乙の傾向は一層明膫になっている [Fig. 3(d), (e)]. なお $1000^{\circ} \mathrm{C}$ で V4 以下の低速引張, $900^{\circ} \mathrm{C}$ で V3 以 下の低速引張ではいずれ屯粒界破断を生じており，伸び 量は少なかった. $1200^{\circ} \mathrm{C}$ の場合は $1300^{\circ} \mathrm{C}$ と $1100^{\circ} \mathrm{C}$ との中間の傾向を示している.

そこで次に $1100^{\circ} \mathrm{C}$ の場合について高速引張として V2, 低速引張として V6 の場合を選んで変形途上で除 荷し, さきと同様に高温顕微鏡を用いて, 再結晶の有無 を調べた. Photo. 4(a) は $1100^{\circ} \mathrm{C}$ で V2 の速度で変形 を行ない,ピーク荷重から少し変形の進んだところで除 荷し恒温保持した場合で，（1）は除荷直後の組織で粒 内変形が進み， B 粒内には双晶ラインが深くみえる.

(2) は恒温保持20分後の組織でA, B粒内に新しい結晶
粘がはっきりと観察される。つまりこの荷重変動量が比 較的少ない $1100^{\circ} \mathrm{C}, \mathrm{V} 2$ の場合にも動的再結晶は抢とり うると考えられる。 Photo. 4 (b) は同様, $1100^{\circ} \mathrm{C}$, V6 の引張変形途上で除荷し，恒温保持した場合のあのであ る.（1）は除荷直後の組織で,（2）は恒温保持17分後 のあので再結晶粒が現出している.

以上の事柄から $1100^{\circ} \mathrm{C}$ では V2 の高速度で変形さ せても，V 6 の低速度で変形させてもいずれの場合も動 的再結晶が生じている。しかし，ての $1100^{\circ} \mathrm{C}$ の V 2 , V 6 の場合の荷重一伸び曲線にはいく分の相違が見られ る.すなわち高速度で変形された V 2 の方がやや荷重 変動が V6 より小さい，乙れは高速変形の時は，加工 硬化し蓄えられた歪エネルギーが，再結晶によってまだ 十分に解放されないうちに，次の歪が重畳されてすぐに また加工硬化がおこるために，荷重変動量が少なくなる むのと考えられる.

このように $1300^{\circ} \mathrm{C} \sim 900^{\circ} \mathrm{C}$ の高温度で引張変形を行 なうと，その荷重一伸び曲線には動的再結晶による荷重

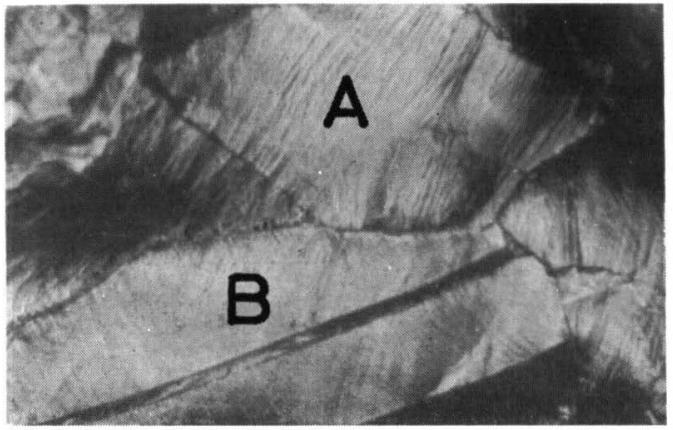

(1)

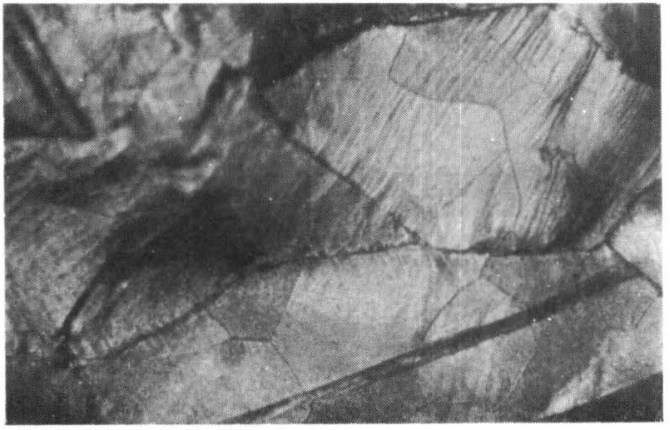

(2)

Photo. 4 (a) Isothermally holded high temperature structures after deformation at $1100^{\circ} \mathrm{C}, \mathrm{V} 2(\times 70 \times 1 / 1)$

(1) Immediately after unloading (2) After holding for $20 \mathrm{~min}$

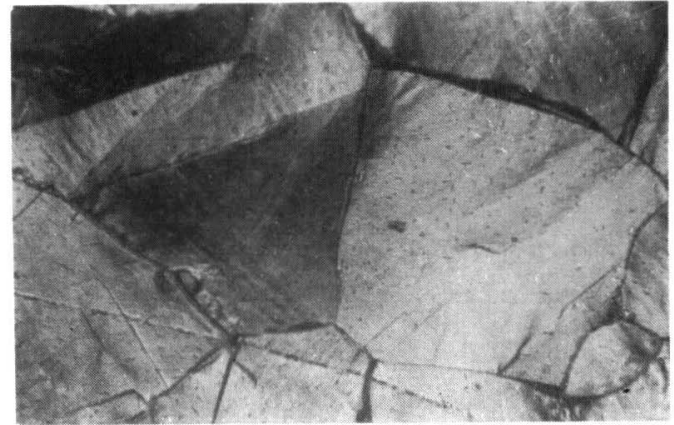

(1)

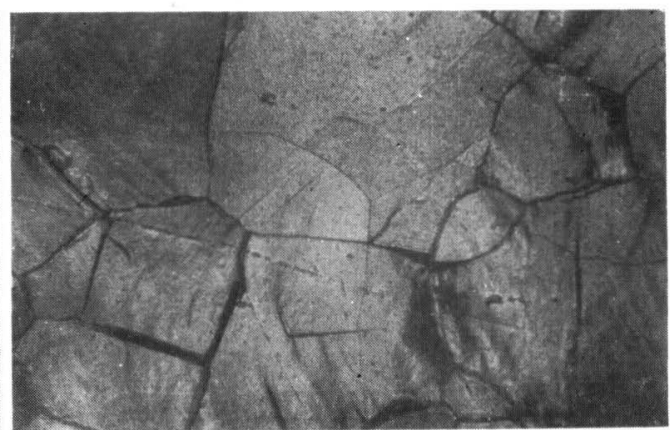

(2)

Photo. 4 (b) Isothermally holded high temperature structures after deformation at $1100^{\circ} \mathrm{C}$, V6 $(\times 70 \times 1 / 1)$

(1) Immediately after unloading

(2) After holding for $17 \mathrm{~min}$ 
の変動がみられ，とれから熱間変形中の動的再結昆現 象を知るこ之ができることがわかった，すなわち，約 $1200^{\circ} \mathrm{C}$ を境にして，これ以上の高温度での变形では変 形速度が大きい程, またてれ以下の温度では変形速度が 小さい程，動的再結昆はおこりやすい。

なお Fig. 5 は引張変形速度を一定にして荷重変動状 態を温度別にみたもので，(a）にV2 の高変形速度の場 合を, (b ) にはV5 の低変形速度の場合を示した。

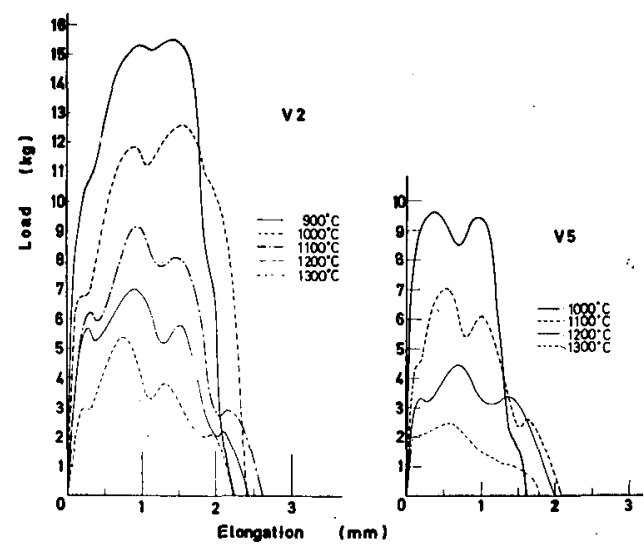

Fig. 5 Change of load-elongation curves for various temperature when tensile rate is constant (a) V2. (b) V5

（3）動的再結晶と活性化エネルギー

次に動的再絬晶のおこりやすさを考えるために活性化 エネルギーの導入を行なった，高温変形の場合，動的再 結昆が抢てるか否かは，加工便化によって現われる最初 のピーク荷重に対応する贸形量に至るまでの過程で蓄え られる歪エネルギーの量によってきまると考えられる。

C. M. Sellars および W. J. McG Tegart ら2つ は熱間 変非の数多くのデータから次の関係式を提案している.

$$
\dot{\varepsilon}=A(\sinh \alpha \cdot \sigma)^{n} \cdot \exp (-Q / R T)
$$

特任低応力の時仕

$$
\dot{\varepsilon}=A \cdot \sigma^{n} \cdot \operatorname{cxp}(-Q / R T)
$$

となる。

ここで

$\dot{\varepsilon}$ : 霆速度 $\sigma$ : 応力

$Q$ : 変形の活性化エネルギー

$R$ : ガス定数 $T$ : 絶対温度

$A, \alpha, n:$ 温度に独立な定数

$n$ の值は普通 2〜4であり, 鋼に関しては多くのデータ 加ら $n=3.5^{33}$ が妥当である。

(1) 式を変形すると

$$
\begin{aligned}
& \sigma^{n}=A^{\prime} \cdot \dot{\varepsilon} \cdot \exp (Q / R T) \\
& \ln \sigma=1 / n \cdot \ln \left(A^{\prime} \cdot \dot{\varepsilon}\right)+1 / n \cdot Q / R T
\end{aligned}
$$

いま $\sigma$ として，荷重一伸び曲線に加工硬化によって現 われる最初のピーク荷重を考え，とれを両対数方眼紙の 縦軸に，横軸化 $10^{4} / T$ をとってプロ゙ットすると Fig.' 6 亿示す折机線状の直線関係が得られる。乙の直線の傾き から変形の活性化エネルギーを求めると Table 3 の上 うになる。乙れから， $1300^{\circ} \mathrm{C}$ で V6 の低速度の変形で はピーク荷重に刘応する変形の活性化エネルギーが約 $73,200 \mathrm{cal} / \mathrm{mol}$ となっており，乙れは $r-\mathrm{Fe}$ の原子の 自己拡散の活性化エネルギー $74,200 \mathrm{cal} / \mathrm{mol}^{4}$ 泉 の值に 非常に近く，この $1300^{\circ} \mathrm{C}$ で V6 の低速引張変形をさ せた時にはピーク荷重に対応する歪が与えられるまで に，原子の自己搪散に上る激しい粒界の移動がみられる はずであり，Photo. 3(b) の（2）（3）にみられたよ うに引張変形途上の激しい粒界移動に対応している。そ してまた，引張変形速度が大きくなるにつれて変形の活 性化エネルギーは小さくなり, 变形が拡散支配機構から 非拡散支配機構へ上変化し, 変形途上の粒界の移動餖は 減少して，結晶粒内部へと変形が及ぼされ，歪エネルギ 一が蓄えられやすくなり動的再綕晶を起こす向のと考元 られる。

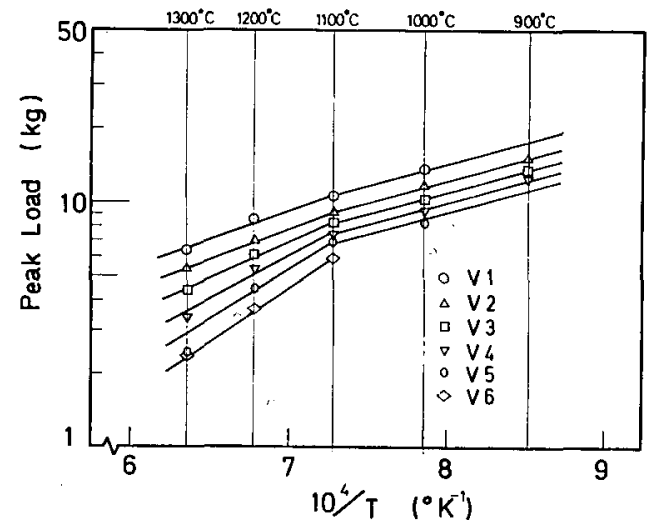

Fig. 6 Peak load vs. 1/T relationship

Table 3 Activation energy for deformation.

\begin{tabular}{c|c|c}
\hline \hline \multirow{2}{*}{ Tensile rate } & Activation energy (cal/mol) \\
\cline { 2 - 3 } & $1300^{\circ} \mathrm{C}-1200^{\circ} \mathrm{C}$ & $1100^{\circ} \mathrm{C} \sim 900^{\circ} \mathrm{C}$ \\
\hline V1 & 34000 & \\
V 2 & 42900 & \\
V 3 & 52200 & 27200 \\
V 4 & 65800 & \\
V 5 & 69700 & \\
V6 & 73200 & \\
\hline
\end{tabular}

そこで高温顕微鏡を用いてての $1300^{\circ} \mathrm{C}$ の場合につい て粒界の移動量の測定を行なった，その結果を Fig. 7 に示す. Table 3 の変形の活性化エネルギ一の変化から 予測されるように V $6 \rightarrow \mathrm{V} 3$ へと引張変形速度が大きく 
なる程, 粒界の移動量は少なくなり, 早く飽和是に達し ている. Fig. 8 にはこの $1300^{\circ} \mathrm{C}$ の場合の粒界の移動 速度を示したもので, 引張変形速度が大きい程, 精界の

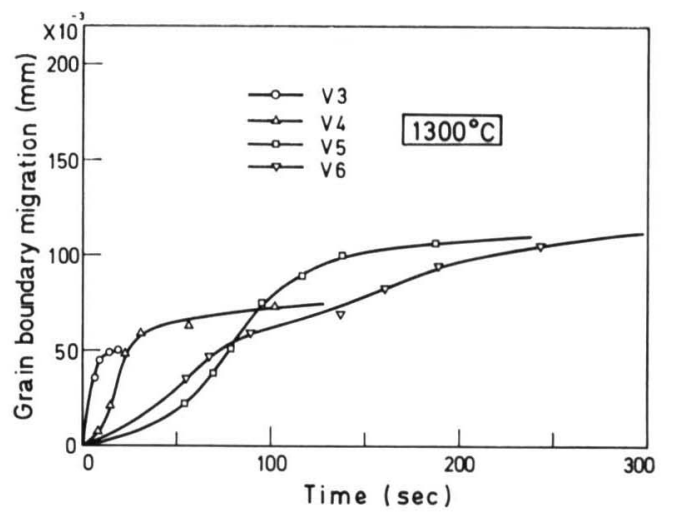

Fig. 7 Grain-boundary migration vs. time curves at $1300^{\circ} \mathrm{C}$

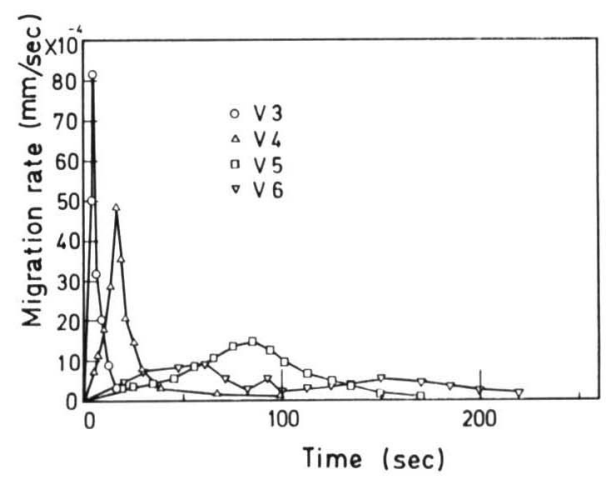

Fig. 8 Grain-boundary migration rate vs. time curves at $1300^{\circ} \mathrm{C}$
移動速度も大きくなっている， $1300^{\circ} \mathrm{C}$ での変形では低 変形速度の時には粒界の移動が激しく, 外部から加えら れた歪エネルギーはこの粒界の移動に費され動的再結晶 はおこりにくいままた $1100^{\circ} \mathrm{C} \sim 900^{\circ} \mathrm{C}$ での変形では引 張变形速度にあまり関係なく変形の活性化エネルギーは ほぼ同じで約 $27,200 \mathrm{cal} / \mathrm{mol}$ である。つまりとの温度 䇡囲内での变形は非拡散支配機構であり, 变形が粒内へ と及ぼされ, 多量の歪エネルギーが蓄えられ，動的再結 晶がおこりやすい状態となっている.

\section{3 高温顕微鏡による高温引張変形時の直接観察}

高温変形下に求ける結晶粒および粒界の挙動に関する 従来の研究としては，金属を熱間加工直後に急冷して得 た熱間加工組織を焼なまし，その間の組織変化から，熱 間変形中における組織変化を推定することが行なわれて いる ${ }^{5}$. ささらに温度や变形速度を変化させ, 変形後急冷 してその切断面からてれらの熱間変形組織に対する影響 などを間接的に調べている五。しかし，いずれもこのよ うな間接的な方法では高温変形下での組織変化, 結晶 粒, 粒界の挙動の追跡は不十分であり, どうしてあ直接 観察が必要になる.

従来, 直接観察による組織变化の研究は, クリープに 関していくらか行なわれているが7，クリープ以外のつ まり高温度で変形速度を種々変化させた場合の研究はほ とんどみられず, 最近, 銀8), 9 を使っての高温圧縮変形 途上の観察がようやく行なわれてきた程度であり，いま だ詳しい研究はなされていない, 特に動的再結晶, その 核の発生状況，再結晶䊀の直接観察はまったくみられな い.

(1) $1300^{\circ} \mathrm{C}, \mathrm{V} 4\left(6.87 \times 10^{-3} \mathrm{~mm} / \mathrm{sec}\right)$ の引張変形 時の観察

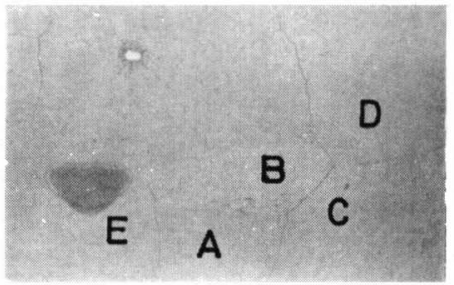

(1)

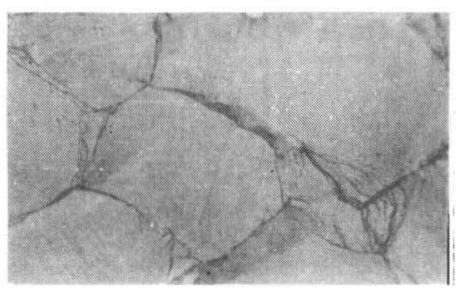

(4)

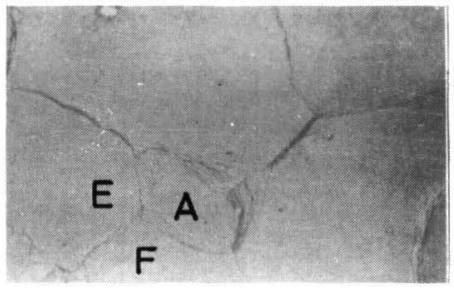

(2)

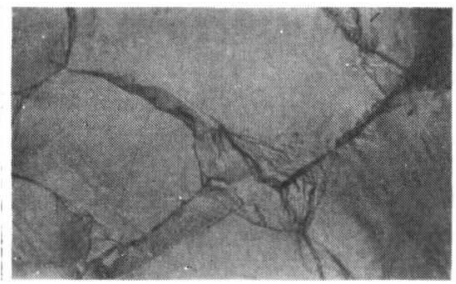

(5)

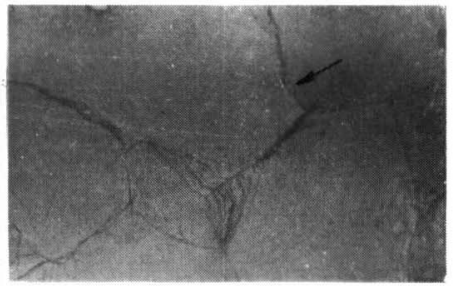

(3)

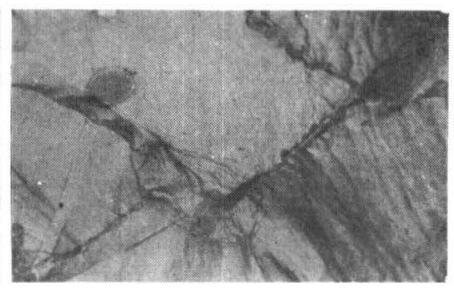

(6)

Photo. 5 High temperature structures during deformation at $1300^{\circ} \mathrm{C}, \mathrm{V} 4(\times 70 \times 2 / 3)$ 
Photo. 5 に $1300^{\circ} \mathrm{C}$ で V 4 の速度で引張变形を行な った時の組織変化を示す（）内は全伸び量（ $\mathrm{mm})$ で ある・

（1）は荷重が作用しはじめて 1 秒後 $\left(6.87 \times 10^{-3}\right)$ の状態でほとんど変化はみられない。こてで各結晶粒に A，B，C․の㲹号を付した.（2）は 8.8 秒後（6.05× $\left.10^{-2}\right)$ で A- B C 粒界三重点が移動しはじめており, $\mathrm{A}$ 粒の併吞がおこりかけている．またA-E-F粒界三 重点む移動を開始しており, その進行方向は A 粒, E 粒 間の粒界方向であるが，（3）の 15 秒後 $\left(1.03 \times 10^{-1}\right)$ になると, この三重点で移動方向は変化してきて A 粒内 部へと向いはじめている.さらにこの（3）の状態には $\mathrm{D}$ 粒内にB-C粒界のちようど延長方向に fold の形成 がみられ，との三重点の近傍に応力の集中がおこり，乙 の部分には大きな歪が加わっていることがわかる. そし てての fold 近傍には粒界からの突出し (bulge) が現わ れはじめ (矢印), しだいに D 粒内部へと変形の進行之 ともに成長していくのがみられる。これは $\mathrm{D}$ 粒内の歪エ ネルギー（転位密度）が B 粒内のそれよりも高いので, このB一D粒間の歪エネルギーの差が駆動力となり，乙 の突出し状の粒界移動がおこったものと考えられる. これはいわゆる歪粒界移動 (strain induced grainboundary migration) である ${ }^{10}$. なおての (4) 以降 の状態にはF 粒内に双晶が観察されている.

その後, 変形の進行とともにA粒の併吞はつづくが, 各粒界の移動はそれほど大きくなく，（5）の57秒（3.91 $\left.\times 10^{-1}\right)$ 以降は変形が粒内人之及んで, 各結晶粒のゆが みがますます激しくなっている，また移動後 $\mathrm{A}-\mathrm{B}-\mathrm{C}$ の粒界三重点には, 大きなクサビ型のいわゆる $\mathrm{W}$ 型ク ラックが観察されている. このことから $1300^{\circ} \mathrm{C}$ の高温
度でも, 変形速度が大きい時には加工硬化を伴う冷間型 の変形を呈することがわかる.

(2) $1300^{\circ} \mathrm{C}, \mathrm{V} 5\left(2.29 \times 10^{-3} \mathrm{~mm} / \mathrm{sec}\right)$ の引張変形 時の観察

Photo. 6 は同様に $1300^{\circ} \mathrm{C}$ でV5 のかなりの低速度 で引張変形を行なった時の組織変化を示す，（）内は 伸び量 $(\mathrm{mm})$ である.

（1）は変形開始 24 秒後 $\left(5.50 \times 10^{-2}\right)$ の状態で, あ まり組織変化はみられない.（2）は 35.2 秒後 $(8.08 \times$ $\left.10^{-2}\right)$ で A-D 粒間, B-C 粒間の粒界の移動がわずか に扟とり粒界が太くみえる．そして 54.5 秒後 (1.25 $\left.10^{-1}\right)$ の（3）には A-B-C粒界三重点 $(P), \mathrm{A}-\mathrm{B}$ 一D粒界三重点 $(Q)$ が移動しはじめている. 三重点 $(P)$ は A一B粒界に沿った方向に移動しており，また三重点 (Q) は B - D 粒界と約 180 度の逆方向の A 粒内へと移動 し，いずれあ A 結晶粒を併吞しようとしている.

変形後 67 秒 $\left(1.53 \times 10^{-1}\right)$ の $(4)$ には, このA粒内 に双晶ラインが観察され, 丕エネルギーが高くなったこ とを示している.（5）の 96 秒後 $\left(2.19 \times 10^{-1}\right)$ には三 重点 $P, Q$ の両者が衝突しているのがみられる (矢印).

(6) の 118 秒 $\left(2.69 \times 10^{-1}\right)$ 位になると三重点 $P$ の移 動方向が変化し， A 粒内部へと向いはじめている. そし て（7）の188 秒位からしだいに粒界の移動は定常状態 になり, 各結晶粒内へと歪が加わり粒内変形および多数 の双晶ラインが観察されるようになる.

ここで結粒粒， B , C , D を横切る直線状のマーカーの 挙動に注目すると, 変形が進むにつれて B-C 粒界で、 一カーが階段を作って切れていく現象が観察される.そ こで $\mathrm{A}-\mathrm{B}-\mathrm{C}$ 粒界三重点 $P$ と直線状マーカーの挙動 について考えてみた。

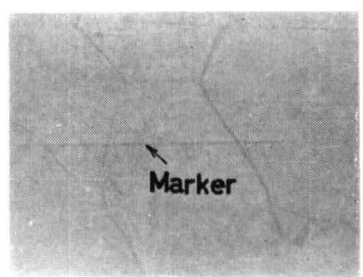

(1)

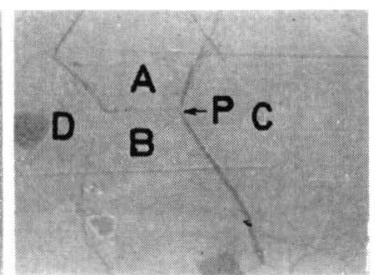

(2)

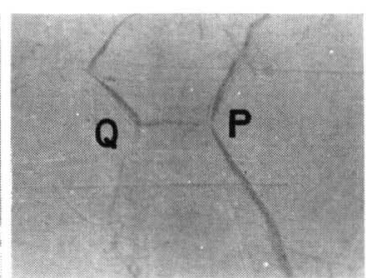

(3)

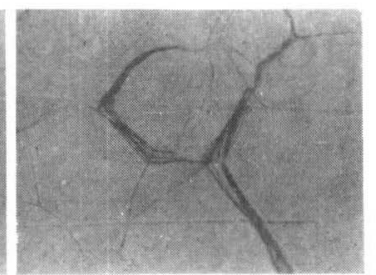

(4)

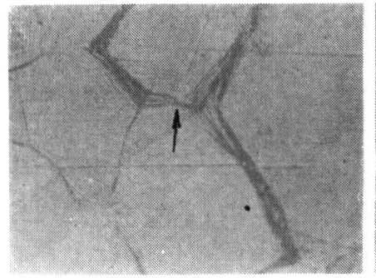

(5)

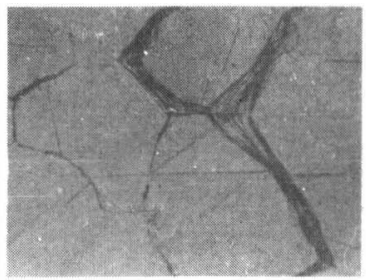

(6)

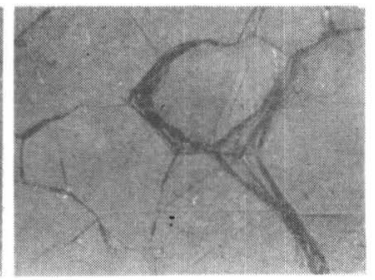

( 7 )

Photo. 6 High temperature structures during deformation at $1300^{\circ} \mathrm{C}$, V5 $(\times 70 \times 7 / 11)$ 
Fig. 9 の図解で示す ( a ) は Photo. 6 の（2）の状 態であり，引張方向は図示のごとくである．引張応力の 絬果, $\mathrm{B}-\mathrm{C}$ 粒界, $\mathrm{A}-\mathrm{C}$ 粒界にはせん断応力 $\tau_{1}, \tau_{2}$ が 作用する。この場合, $\mathrm{B}-\mathrm{C}$ 粒界の方が $\mathrm{A}-\mathrm{C}$ 粒界より も引張方向に対して 45 度の角度に一層近くなっている ので， B-C粒界に作用するせん断応力 $\tau_{1}$ の方が大き い.

（b）はまず第一段階であり，せん䉼応力 $\tau_{1}>\tau_{2}$ のた めに粒界三重点 $P$ は $1 \rightarrow 2\left(P \rightarrow P_{2}\right)$ へと動く. また直線 マーカーは $1^{\prime} \rightarrow 2^{\prime}$ へと動く. この時, $P$ は原子拡散によ って，またマーカーは機械的なすべりによって動くと考 えられる。

(c) の第二段階になると，今度はせん断応力 $\tau_{2}^{\prime}$ に より, 三重点 $P_{2}$ は $2 \rightarrow 3\left(P_{2} \rightarrow P_{3}\right)$ へと動く. (d ) の 第三段階も同様に考えて, 三重点 $P$ は $1 \rightarrow 2 \rightarrow 3 \rightarrow 4(P \rightarrow$ $\left.P_{2} \rightarrow P_{3} \rightarrow P_{4}\right)$ へ上移動する。 このように粒界三重点 $P$ は交互にジグザグに移動していくものと考えられる. Photo. 7 はその状態を図解したものである。これから 粒.界三重点は变形途上では粒界での機械的なすべりと原 子拡散によってジグザグに交互に䉼続的に移動していく
様子がみられる。

(3) $1100^{\circ} \mathrm{C}, \mathrm{V} 5\left(2.29 \times 10^{-3} \mathrm{~mm} / \mathrm{sec}\right)$ の引張变形 時の観察

次に $1100^{\circ} \mathrm{C}$ でV5 の低速度変形を行なった時の観 察結果を Photo. 8 に示す。（）内は全伸び量 $(\mathrm{mm})$ である。

（1）は荷重が作用する前の状態で, ここに各結晶粒 に記号を付す.（2）は約 37 秒後 $\left(8.41 \times 10^{-2}\right)$ の組織 で E一A 粒界が太くなってみえ, おそらくきれつが生じ ているものと思われる.（3）の 87 秒後 $\left(1.98 \times 10^{-1}\right)$ になると $\mathrm{A}-\mathrm{C}$ - D 粒界三重点に明らかにクサビ型のW 型クラックが生じており, $1300^{\circ} \mathrm{C}$ で同じ V5 の速度の 変形でみられた粒界三重点の挙動とはかなり様相を異に している. $1300^{\circ} \mathrm{C}$ の高温度では原子の拡散が激しいた め, 粓界の移動が非常におこりやすく, 引張による歪エ ネルギーが非常に解放されやすい。しかしこの $1100^{\circ} \mathrm{C}$ では拡散がおこりにくく，3・2 節にも述べたように変 形が非拡散的支配下にあるので，引張によって生じた歪 は解放されにくく, 粒界にはきれつが生じ, 結晶粒内, 特に粒界近傍部は歪エネルギー（転位密度）の高い状態

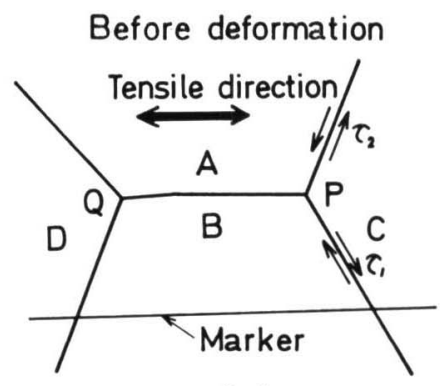

(a)

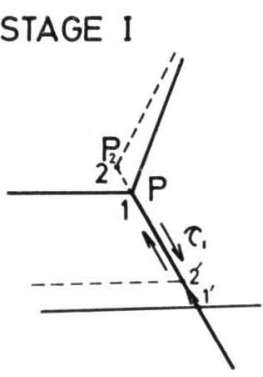

(b)

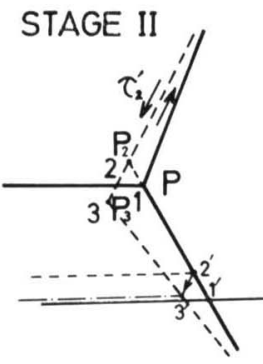

(c)

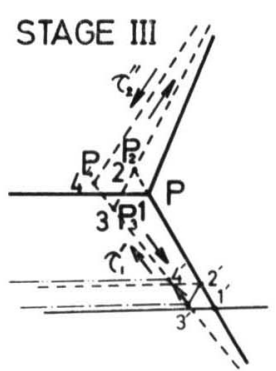

(d)

Fig. 9 Schematic diagrams showing the migration of triple point
(a) The start
(b) Stage I
(c) Stage II
(d) Stage III

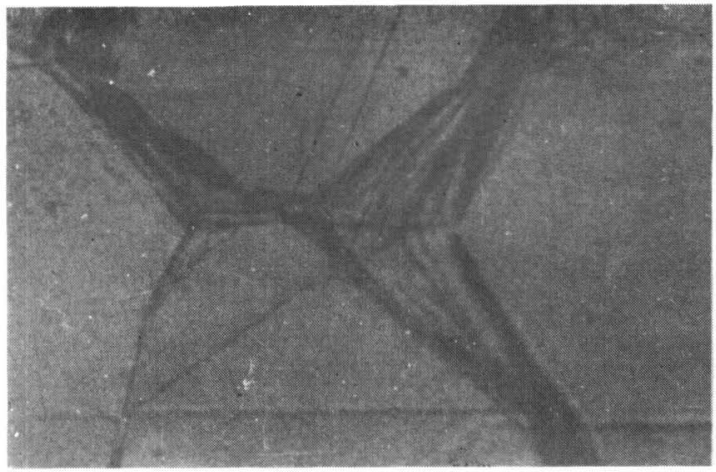

(1)

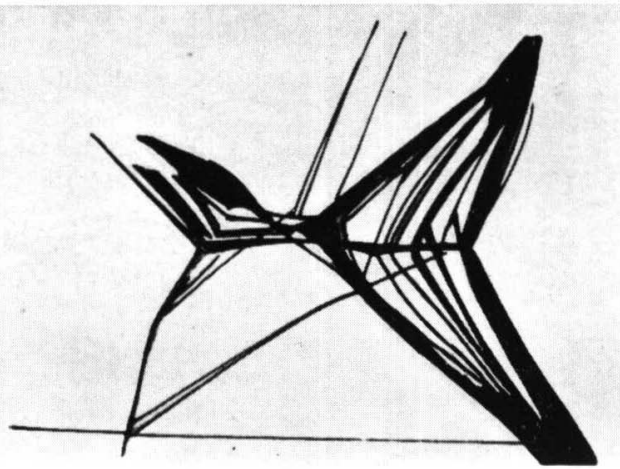

(2)

Photo. 7 Photograph of (6) showed in Photo. 6 and its schematic drawing The zigazg path of triple point is clearly shown 


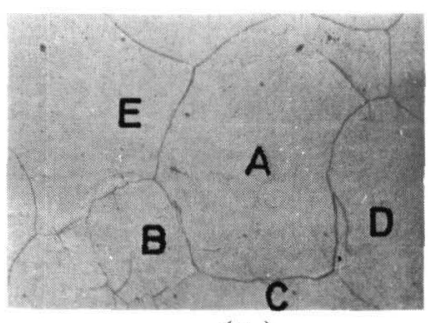

(1)

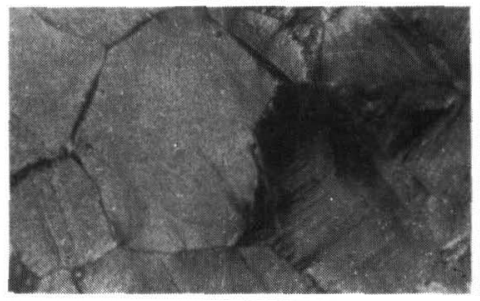

(4)

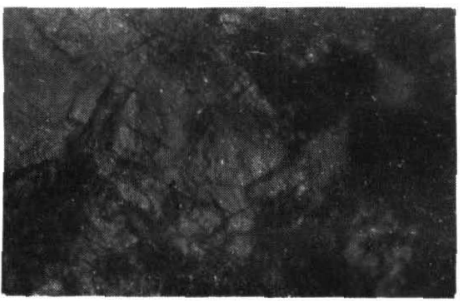

( 7 )

となる。

さらに変形が進むにつれて $\mathrm{A}-\mathrm{B}-\mathrm{C}$ 粒界三重点から A 粒内人之 fold の形成がみられる。また矢印の部分か ら突出し (bulge) がでて転位密度を下げようとしてい る.しかしこの突出しはその後, 成長はしていない. E 䊀内の絬晶粒成長過程で取り残された粒界 $\mathrm{G}$ に応力が 集中し， E粒の表面は折机曲がったようになっており， かなり歪エネルギーの高い状態となっている．さらに変 形が進んで（6）の 447 秒後（1.02）になると，A粒内 の下側近傍に動的再結晶粒と思われる新しい結晶粓が出 現しているのが観察される.

ここでこの動的再結晶粒の生成について考えてみる. （5）から（6）の撮影の間隔は約 47 秒であり，この動 的再結晶粒の出現過程を詳細には捕えているとはいえな い. しかし変形の進行状態から判断して，この47秒間に 急激に新しい核の発生があり，それが成長したあの上考 えられ，元の結晶粒界の移動などによって生成されたも のではない，さらに変形が進んで（7）の約 535 秒後 (1.25) には,さらに多くの動的再絬晶粒が観察されて いる.

（4）本観察結果からの動的再絬晶粒生成についての 推㖮

熱間変形中の絬晶粒界の移動や動的再結晶などに関す

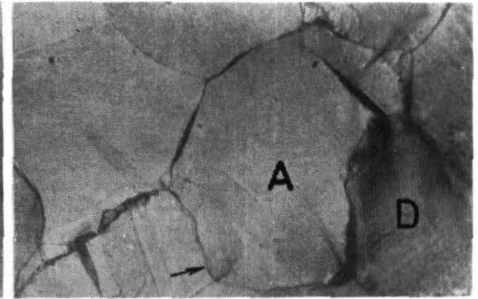

(3)

(2)

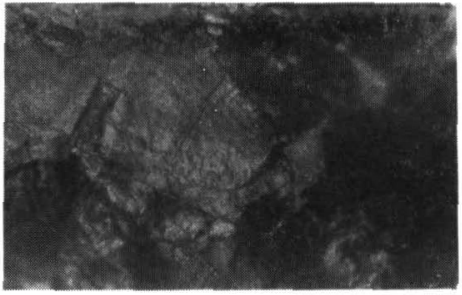

(5)
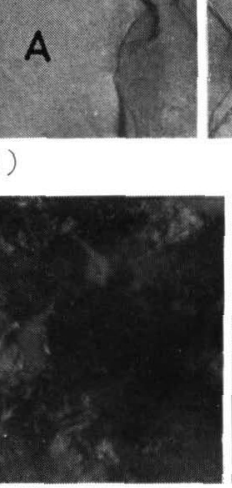

(6)

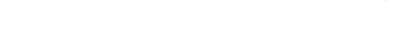

deformation at

Dynamic recrystallization is photographed in $(6),(7)$
る研究は少なく, 先述したように著者らの知るかぎりで は，銀について行なわれたものしかない，従来行なわれ てきた粒界移動や再結晶の研究は, 冷間加工材の焼なま し過程におけるつまり静的再絬晶に関するものがその大 部分である，乙の静的再結晶に関する研究から，再結晶 の核生成機構に関しては

（1）結晶粒界の移動（2）サブ結晶粒の成長 の 2 つの考え方がうち出されている11).

熱間変形時には, 変形による丕エネルギーの解放と蓄 積が同時におこるために, この静的再結晶現象がそのま ま動的再結晶現象にあてはまるか否かはわからないが, とむかくこの本供試材 $80 \mathrm{~kg} / \mathrm{mm}^{2}$ 級高張力鋼の場合に は, 動的再結晶粒の核の発生, 成長があり, それは粒界 近傍の歪の大きな部分に生ずるあのであって, 元の結晶 粒界の移動によって生成されるものではないと結論し た。

なお銀の圧縮検鏡によれば, 熱間変形中は粒界移動, 粒界すべりのみがおこり, これによって歪は解放される ので再結晶核の発生, 成長はおこりえないとしている.

\section{4. 結論}

引張型の高温顕微鏡を使用して供試 $80 \mathrm{~kg} / \mathrm{mm}^{2}$ 級調 質高張力鋼について高温変形下における結晶粒界の挙動 
を調べた。結果をまとめると，大要次の結論が得られ る.

1) 高温引張変形時の荷重一伸び曲線圭求めた．この 曲線にはいずれも変形途上で激しい荷重の変動が認めら れ，乙れが動的再結晶によって現われるととを確かめる ことができた、さらにこの荷重一伸び曲線および変形の 活性化エネルギーを考えて熱間変形下における組織変化 を推定することができた。

2) $1300^{\circ} \mathrm{C}$ での変形で，変形速度が大きくなる程, 粒界の移動速度は大きくなり，早く飽和晴傽すること を高温顕微鏡を用いて示した。

3 ）引張变形途上の粒界三重点の移動は，機械的な粒 界すべりと原子掋散によると粒界移動によって起こるこ とをマーカーを使って観察し，かつその移動は交互にジ グザグに進行していくことを明らかにした。

4) 動的再結晶粒を $1100^{\circ} \mathrm{C}$ でV5 の低速度の変形 に際して直接観察を行なった，高温顕微鏡を用いてのそ の表面組織のみから判断してではあるが，高温変形下で の動的再結晶粒の核は，粒内の粒界近傍部に優先的にか つ偶発的に発生し，元の結晶粒界の移動によって生成さ れるのではないと結論した。

\section{謝 辞}

本研究を遂行するにあたり，たえず御教示を賜わりま した東工大石井勇五郎教授に，また試験片製作に御尽力
下さいました船舶技研の方々に梁く謝意を表します。

\section{参 考 献}

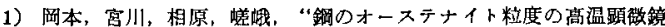
榷察”, 金属学会热, Vol. 28 (1964), No. 6, 341 385.

2) C.M. Cellars, W.J. McG. Tegart, "On the Mechanism of Hot Deformation", Acta Met., Vol. 14 (1966), No. $9,1136 \sim 1138$.

3) F. Garofalo, "Fundamentals of Creep and CreepRupture in Metals", Macmillan, (1965)，邦訳：足卉正婎 訳, “金属クリーブの基喏”, 丸普, '1968)，96。

4) W. Hume-Rothery, "The structures of Alloys of Iron"; An Elementary Introduction, Pergamon Press,

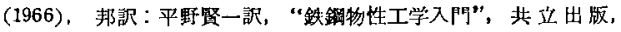
(1970), 285.

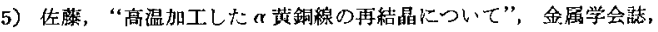
Vol. 25 (1961), No. 6, 385 389.

6) 例之ば, M.J.Luton, C.M.Cellars, “Dynamic Recrystallzation in Nickel and Nickel-Iron Alloys During High Temperature Deformation", Acta Met., Vol. 17 (1969), No. 8, $1033 \sim 1043$.

7) 例えば，H.C.Chang, N.J.Grant, "Observation of Creep of the Grain Boundary in High Purity Aluminium" Trans. AIME, Vol. 192 (1952), No. 6, 619 525.

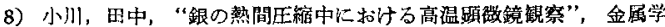
会获, Vol. 32 (1968), No. 10, 988 993.

9）小川, “銀の高温厌縮中心打汁る粒界移動”，金属学会志，Vol，34 (1970), No. 12, 1177 1184.

10) P.A. Beck, P.R. Sperry, "Strain Induced Grain Boundary Migartion in High Purity Aluminium" Vol. 21 (1950), No. 2, 150 152.

11) J. Gerald Byrne, "Recovery Recrystallization and Grain Growth", Macmillan, 1965, 邦駅：小原呞的訳, “回 復括よび再結晶”，九善，1968，83， 